\title{
PERSONAL EXPERIENCES OF BIOECONOMY DEVELOPMENT: AUTOETHOGRAPHY APPROACH
}

\author{
Erika Zabulioniené ${ }^{1}$, Rasa Pranskūnien $\dot{e}^{2}$ \\ ${ }^{1}$ Master of Social sciences, Vytautas Magnus University, Lithuania. E-Mail address: erika.zabulioniene@vdu.lt \\ ${ }^{2}$ Doctor of Social sciences, Associated professor, Vytautas Magnus University, Lithuania; Universiteto str. 10, Akademija, \\ Kaunas distr., 53361. Phone No. +370-615-18332, E-Mail address: rasa.pranskuniene@vdu.lt, ORCID ID: 0000-0001- \\ 5047-8043
}

Received 2908 2021; Accepted 30082021

\begin{abstract}
As nowadays we are experiencing the boom of Bioeconomy, this paper presents the evolving results of autoetnography study. Waste and by-product use are the key issues related to the bioeconomy, so this paper seeks to present the everyday experiences linked to bioeconomy challenges, choosing to debate daily experiences as the narratives in personal level. The presented personal experiences, as short stories, reveal the complexities of daily choices, doubts and daily reflections between fun and playfulness, between guilt and uncertainty. The discussed autoetnography experiences lead to deeper discussion about the dilemma of challenging daily life living in bioeconomy times, opening up the intertwined personal narratives. As well, this study shows the importance to discuss the various research paradigms that would help researchers discover new insights and develop new studies, explaining the challenges and daily intertwining individual experiences living in bioeconomy era.
\end{abstract}

Keywords: Bioeconomy, Autoetnography, Experience.

JEL Codes: Q01, D91, E71, I25.

\section{Introduction}

Bioeconomy and sustainable development became two central pillars of many countries' national policies (Issa et al., 2019; Scarlat et al., 2015). As such, bioeconomy integrates solutions oriented to more sustainable future. As well, bioeconomy's overall idea and concept can contribute to solutions for current environmental problems (Stern et al., 2018; European Commission, 2012).

Drabble (2018) points out, that the traditional scientific approaches to writing are still predominant. Thus, these approaches require 'researchers to minimize their selves, viewing self as a contaminant and attempting to transcend and deny it' (Wall, 2006, p.147). According to Scarles and Sanderson (2016) proposing researchers are repositioned when they are themselves 'becoming researched' in the subjective shift within autoethnography. Therefore, as the object of the article are everyday bioeconomy self-experiences, the aim of the article is to present the evolving results of autoethography study and to discuss the importance of use the reflexive methodologies in nowadays bioeconomy research.

Bioeconomy is a not only dynamic, but as well, complex societal transformation process, requiring a long-term policy perspective (Chavarria et al., 2020). To be successful, as European Commission (European Commission, 2018) mentions, the European bioeconomy needs to have sustainability and circularity at its heart. The bioeconomy is about the "biologization" of industrial value creation.

Copyright (C) 2021 Author(s), published by Vytautas Magnus University. This is an open access article distributed under the terms of the Creative Commons Attribution Non-Commercial 4.0 (CC BY-NC 4.0) license, which permits unrestricted use, distribution, and reproduction in any medium provided the original author and source are credited. The material cannot be used for commercial purposes. 
It supplies renewable carbon to the industry and can directly replace fossil carbon in almost all areas - in contrast to minerals and metals (Carus, 2020). The bioeconomy seeks the society to transform the way of linear thinking to a more sustainable, as well as circular thinking (Colmorgen et al., 2020). According to Guellec et al. (2020), the concepts such as "bioeconomy" or "circular economy" are often suggested as a possible solution to environmental problems, where the central concern should go to the critical interplay between demand and supply for resources. Although bioeconomy research currently focuses on the natural sciences and engineering, as Bugge (2016) argues, the link between the bioeconomy and it's wider socio-economic implications is becoming an increasingly important topic for future research.

Kuckertz (2020) points out, that transformation toward the bioeconomy seems desirable. While some strategies recognize that bioeconomy entrepreneurship projects should require public funding (e.g., the German and the US bioeconomy strategy), such strategies also build on existing framework programs to support innovation in their respective economies. Waste and by-product use, as Viaggi (2018) notices, are key issues related to the bioeconomy, so this study seeks to present the everyday experiences linked to bioeconomy challenges.

\section{Material and methods}

According to Lobe et al. (2020), living at unpredictable times due to COVID-19, qualitative researchers face unique opportunities and challenges. As well, qualitative analysis let us to open up the unexpected insights (Sari et al., 2020; Krisciunaite, Pranskuniene, 2020; Pranskuniene and Perkumiene, 2021, etc.). As autoethography was used for the study, it's important to discuss the place of self reflexivity in social sciences. Scarles and Sanderson (2016) notice, in recent years, there has been a wealth of literature attending to 'situating' the researcher through self-reflexivity (see for example: (Adkins, 2020; Cloke et al., 2003;
Crang, 2003; Denzin, Lincoln, 2000). Rather than moving to deny the inherent reflexivity of research, autoethnography fully embraces the subjectivity of researcher. As Krieger (1996) suggests, there becomes the need to resituate the ' $\mathrm{I}$ ' in research and generating a series of affiliations and insights, developing a fuller sense of self, seeking our understanding of others would not become become artificial.

Autoethnographers and qualitative researchers in general emphasize that reality is neither fixed nor entirely external, as Duncan (2004) notices, but is created by, and moves with, the changing perceptions and beliefs of the viewer. Here, as Scarles and Sanderson (2016) argue, subjectivity becomes constructive rather than destructive, accessing 'hidden' spaces, stimulating creativity and deepening connection. Therefore, autoethnography is an approach to research and manner of presentation of obtained results aiming to describe and analyze personal experiences and as a result attempting to understand cultural experiences (Marcysiak and Prus, 2017). Costello et al. (2016) notice, that the application of autobiographical writing in science has developed as a genre of qualitative research throughout the postmodern era.

According to Stephens Griffin and Griffin (2019), autoethnography can be understood as the process of inter-relating fieldwork findings with the analysis of personal experiences. Thus, as a method, it is both process and product (Ellis et al., 2010). And researchers here recognize the innumerable ways how personal experience influences the research process (Ellis et al., 2010), as well, "as an autoethographer, I am both the author and focus of the story, the one who tells, and the one who experiences, the observer and the observed, the creator and the created" (Ellis, 2016, p. 13). Thus, Ellis and Bochner (2006) explain the meaning of autoetnography in such a way: when we take apart the term, auto-ethnography, we get auto, meaning self; ethno meaning culture(s); and graphy meaning description. 


\section{Sciendo}

Management Theory and Studies for Rural Business and Infrastructure Development

eISSN 2345-0355. 2021. Vol. 43. No. 3: 346-353

Article DOI: https://doi.org/10.15544/mts.2021.31

\section{Results and Discussion}

According to Birner (2018) citizens may also be critical of the bioeconomy. The experience of bioeconomy to the authors of the article came as a surprise: when the organization, where we work deepened the mission and goals and one day when sitting in a cafe and drinking juices with a straw, just came the wonder - what does "straw" mean to me? And what does sustainable consumption and my harmony with nature mean to me personally? And why could "the straw" be symbolically connect all the experiences that have been associated with sustainable consumption or damage to nature. Thus, it was started to keep track of the experiences writing them down. The bioeconomy experiences emerged from the daily life observations. This is how the autoethnography method came: as Adams et al. (2015) point out, "When we do autoethnography, we look inward into our identities, thoughts, feelings and experiences and outward into our relationships, communities and cultures" (p. 46). As the concept of bioeconomy includes human thinking, it is transformation. Thus, we should think about the transformation, including not only the dynamics and complementarity of various technological, organizational, economic, institutional, socio-cultural, political but, as well, the systems of environment (Leach et al., 2010; Urmetzera et al., 2020).

As the results of study there are presented the shorts stories of self experiences:

Short story: Experiencing the straw. "I am very fond of drinking different drinks with a straw. I always ask the waiter to bring it to me. It is very good for me to drink with a straw - it is a kind of relaxation, meditation. And a lot of fun. However, in the world, I am already hearing the tendency for straw to be abandoned because plastic is very polluting to nature. I sort the trash - plastic, metal, cardboard, glass, various cosmetic packaging. However, the straw dilemma leads me astray - what's more important the straw or the planet? I'm angry: the straw is so small, how can it harm the planet? I need it so much. Without it, I can't live - I can't drink. Inside, it cuts like that. What an injustice is to deprive me of something very precious. Those around you say drinking with a straw is a sin. But I was thinking - nothing will happen here - sweet sin. I'm not ready to give up that straw yet. I wait for the environment - the state to come up with another solution. And so, I live in that dilemma - a little confused about what to choose - everyday joy, or the well-being of the earth. And I find it difficult".

Short story: Experiencing the empty coffee cup. "Recently I went on a trip to the very cozy corner of nature - the Museum of Ancient Villages, where there is a lot of nature and traditions of our Lithuanian ancestors. Educational - tourist trip. Nice guide, lots of space, beautiful nature. And suddenly, on the footpath, I saw an empty cup of coffee from a gas station. There's nothing around - just this one mug. He's so annoying to me: Well, you guys are, how can you start dropping a cup of coffee on the ground? Just, it looks like you walked, drunk, and without thinking, you drop that mug on the trail. And you went. And nothing. Oh, I'm thinking, is that easy? Did he really go and flash - dropped it or was he a bit ashamed or uncomfortable? Because when I saw that cup, it was really awkward. I thought that cup thrower was doing something really obscene. I was uncomfortable looking at that trash. It was just lying there alone on this trail, digging passerby eyes so obtrusively. Human non-culture. Unpleasant, inconvenient for another...".

Short story: Experiencing recycling. "I sort the trash - plastic, metal, cardboard, glass, various cosmetic packaging. Well, I don't even remember how the idea came to me, because in the past it just seemed like a tedious affair that would require me extra effort and it's not clear what the benefits would be. But as time went on, some people sorted and I probably matured for this beautiful act. I am definitely for sorting 
and recycling. I take the waste to a dedicated bin at home, then take it out and dispose of it in the appropriate containers that are right next to our house. And when I throw away that recyclable packaging, there is such an inner joy that I do not throw it into the general trash, I take it to a dedicated bin. And the most fun part of sorting is sorting them into different containers. It is such a pleasure, joy and inner satisfaction that we even compete with my son who will pack as many packages as possible into containers. It's like a game - it's fun for both of us. Even if we are not competing and I sort the waste alone - I feel good, because I know that all the pleasure will come to me alone. And it drives me on!"

Short story: Experiencing Sustainable marketing. "Once I was looking for a gift for my sister and went to a Lithuanian natural cosmetics store. I looked around, chose and went shopping. There was a small announcement on the counter - you will get 30 percent discount on selected cosmetic product, if you bring them 3 empty containers of that cosmetics. Well, again, for you, MOTIVE. But not discount here is the key. I already sort trash, so collecting and bringing those empty packages is not that difficult. Even fun. Again, it's like a GAME. And yet useful to me personally. And to nature".

Short story: Experiencing Sustainability and clothing. "What about clothes? I'm a woman. I like to dress nicely. I love to change. However, I have noticed that I usually wear a few selected clothes that I like the most, that I feel most comfortable with, that fit me. And despite the fact that the closet has enough clothes and I don't need any more - I want to buy new ones. Nowadays we have everything you go to the supermarket and you see so many clothes, shoes, things. We have so much of everything. And you go to that mall and there's a new dress there - fun design, beautiful color, shape. And you buy. Despite the fact that there are 5 more dresses hanging in the closet, which, when newer and prettier, appear to be wearable. Insensibly I feel, that I am becoming a part of the consumer society. And so, the wheel spins: old clothes hang in the closet, I buy new ones, then I want to get rid of the old ones that I no longer wear or are tired of. On the other hand, there are currently several ways of disposing of old-wear clothing: given to charity; carry in clothing containers next to the secondary sorting containers; selling on the Internet on dedicated online platforms; it is also possible to bring old clothes and get a discount on new clothes, as one famous brand offers. These are, again, certain marketing processes but geared towards nature conservation. However, this method does not force people to consume moderately, and vice versa - you buy new things, which means that you have to get rid of the old ones so that you have to place new ones and so on. And so, the consumption wheel spins. But, of course, we have to thank the business that there are still signs of nature conservation and recycling and / or recycling of secondary raw materials. I think this is a responsible business".

Short story: Experiencing Straw again. "The topic of "Straw" is related to one of my friends, with whom we unexpectedly started this topic and with whom we are constantly continuing it, developing in our conversations and reflections. We were both so impressed with the "straw" topic that we even attended a bioeconomy conference. The same friend, knowing my doubts about using the straw, gave me a metal straw one day. This new longlasting straw of mine even has its own brush for cleaning the straw. A very delicate gift. However, this environmentally friendly solution has also given me a lot of thought about whether it is really less polluting? E.g. how long can he with his brush be thrown in the trash lying on the ground? Plastic straw is bad, and is metal better, rather than paper? After all, then the trees, the basis of our existence, suffer again. These ideas encourage further deepening into the issues of sustainability and environmental sustainability. Unexpectedly, the ordinary meeting of friends becomes to the rethinking about the solutions of global problems". 


\section{Sciendo}

Management Theory and Studies for Rural Business and Infrastructure Development

eISSN 2345-0355. 2021. Vol. 43. No. 3: 346-353

Article DOI: https://doi.org/10.15544/mts.2021.31

Short story: Experiencing COVID-19 times. "Until I wrote my experience everything in this world was fine. But suddenly - one - and the world was shaken by the corona virus. Initially, we watched the events on TV, and later, as the virus spread, our state issued a quarantine. So that quarantine feels very strange. There has been a decline in people on the streets, in shops, in vehicles, in limited entertainment, and even in walks in the park. At first, I looked at it all calmly, without panic. But later, the more I watched the TV news, the more anxiety I began to feel. But even though a lot is limited, you have to go to the grocery store. So, I went. I went to one, another small grocery store - vendors with disposable gloves. Well okay, seeing this is already normal. All is well, after all, it is a necessity that protects us from becoming infected with the virus. Then I see a female shopper next to me with disposable gloves. I go outside, I see a woman with a disposable mask and gloves. Oh, God I think, and I'm without any protection. I go to the pharmacy - they no longer have disposable gloves or disinfectant. Everything the state has received today is for physicians. Oh, I thought, I was already late to buy. I worry even more. I enter the supermarket, and there hangs a bunch of thin disposable gloves at the entrance. I take the pair and cover myself, I take another one and secretly put in the bag - next time, or for another walk outside - after all, nothing can be touched anywhere in public places ... especially since nothing can be bought in pharmacies. So, I shop with disposable gloves, put fruits and vegetables in disposable polythene bags. All last night, I insanely wanted croissants, so I got access to the buns, and they were packed in disposable paper bags of two, three each as needed. I would throw in 2 plain, 2 chocolate croissants and 2 donuts in case I could go to the store less often. After all, you want that sweet, especially when you know you can't walk around the shops too much and anxiety arises and it becomes your means to get rid of that anxiety a bit. Later I went home and started thinking about what I had seen and experienced.
Thus, what my postings about disposable bags, cups, straws, gloves, etc. are worth now. After all, now these things are vital to us, they are our protection against the virus, they can save our lives or at least reduce the risk of getting it. That's how suddenly things turned around and I wonder what my "straw" means to me now. What I considered evil is an invaluable good right now".

Short story: Experiencing the lock down. "Strange. The quarantine ended and some entanglement remained. Every time I go to a public place I think - what if? What if I get infected? What if? I'm still looking for disposable gloves and a disinfectant at the store, I feel uncomfortable on public transportation. Everything seems to be the same as in the past, but not yet... Other people also still do not let others closer, avoid one to give another hand. Me too. I got used to going to the store less often, washing my hands all the time. My friend even said after the quarantine that she was not yet ready to meet people live in a larger gathering. Somewhere on the side of consciousness, and maybe not even on the side, but very close, right here lies the corona virus and annoys me - binds. Somehow uncomfortable around. You don't want to get very close to each other, show attention. Even if you try to forget it, pretend. You can't. Because he's gone nowhere - still standing somewhere by the side, somewhere very close".

The presented shorts stories of self experiences led to the deeper discussion on bioeconomy experiences, and it is presented in next section. Autoethnography let us to share individual bioeconomy experiences and to create the importance of personal experiences opening new meanings, as well as, new understandings, via lived experiences expressed through presented short stories. The stories show, that bioeconomy integrates a number of solutions for a future that is more sustainable as well as offers an exciting space for research and debate. As Duncan (2004) notices, that in an autoethnography, the researcher is, in fact, the insider, here the 
context is his or her own, and the use of self is the only data source, as Holt (2003) arques. Thus, the positions of academic writers here are as the objects of research, and as the subjects researching their own situated contexts, as Olmos-López and Tusting (2020) arque. Interestingly, only the changes in the immediate environment inspired to reflect and led to take notes on what I see, feel, and perceive. The further away, more starting to "catch knowledge" the environment on the topic of bioeconomy was observed. These personal insights and notes have helped to see how we can approach the changes leading to different, responsible consumption on a daily basis, to see what we can do, how we can contribute myself. The small steps towards the "bioeconomy" in the individual life: straw, a cup of coffee, clothes, cosmetics. For everything that leads to "bio", towards a greater harmony with nature. Thus, as Hynes et al. (2020) argue, that the world works, as the complex of systems, where the systems are interacting with each other and interchanging both in this interaction and the links between them. Schrevel et al. (2020) point out, that providing narrative descriptions of lived experiences, can provide invaluable examples, insights, and inspirations for other researchers in the field.

\section{Conclusions}

The presented shorts stories of self experiences reveal the complexities of daily choices, doubts and daily reflections, between fun and playfulness, between guilt and uncertainty. These stories open deeper discussion about the dilemma of challenging everyday living times in bioeconomy era. Metaphorically speaking, as Küpers (2020) notes, the Earth is a body that is inflicted with serious ills and research, released, understood and valued in everyday life can help practically in wise sensing, feeling, thinking, deciding, as well as, reveal interacting cycles of sustainable development that are as much embodied mindful as 're-evolutionary'. Research, released, understood and valued in everyday life, can help practitioners to understand, feel, think, make decisions, as well as reveal interacting cycles of sustainable development that are as inspiring as they are conscious. As well, this autoethography study shows, that it could be the paradigm that would help researchers discover new insights and develop new studies, explaining the challenges and the everyday experiences living in bioeconomy era.

\section{References}

Adams, T. E., Holman-Jones, S., \& Ellis, C. (2015). Autoethnography: Understanding qualitative research. Autoethography, New York, NY: Oxford University.

Adkins, L. (2002). Reflexivity and the Politics of Qualitative Research. In Qualitative Research in Action, ed.; May, T., London, Sage: 332-348.

Bioeconomy Summit Communique of the global bioeconomy summit 2015: making bioeconomy work for sustainable development, Berlin, 2015.

Bonaiuti, M. (2014). Bio-economics. In Degrowth: A vocabulary for a new era, D’Alisa G, Dematia F, Kallis G (eds), Routledge/Taylor \& Francis Group, Abingdon/Oxon: 52-55.

Bugge, M.M., Hansen, T., Klitkou, A. (2016). What Is the Bioeconomy? A Review of the Literature // Sustainability Vol. 8. No. 7: 691.

Carus, M. (2020). The bioeconomy is much more than the bioeconomy // BLICKWINKEL. The Quarterly Periodical by BRAIN AG, 2020. - https://www.brain-biotech.com/blickwinkel/circular/the-bioeconomy-is-much-morethan-a-circular economy/

Chavarria, H., Trigo, E., Pablo, F. V., Piñeiro, V. (2020). Bioeconomy: A Sustainable Development Strategy // G20-Insights. Policy Area: Sustainable Energy-Water-Food-Systems, 2020. - https://www.g20-insights.org/wpcontent/uploads/2020/07/bioeconomy-sustainable-development-strategy-1594128879.pdf.

Cloke, P., Crang, P., Goodwin, M., Painter, J.M., \& Philo, C. (2003). Practising Human Geography. Sage Publications Ltd, London.

Colmorgen, F., Khawaja, C. \& Rutz, D. (2020). Handbook on regional and local bio-based economies, 1st Ed; WIP Renewable Energies, Munich, Germany. 
Costello, J., Feller, J., \& Sammon, D. (2016). On the road to trusted data: an autoethnography of community governance and decision-making // Journal of Decision Systems, Vol. 25. No. 1: 182-197.

Crang, M. (2003). Qualitative Methods: touchy, feeling, look-see? // Progress in Human Geography, Vol. 27. No. 4: 494-504. London.

Denzin, N.K., \& Lincoln, Y.S. (2000). Handbook of Qualitative Research, 2nd Ed.; eds., Sage Publications, Inc.,

Drabble, N. (2018). It's all about 'me' with you: Exploring autoethnographic Methodology // Spark: UAL Creative Teaching and Learning Journal, Vol. 3. No.1: 5-15.

Duncan, M. (2004). Autoethnography: Critical appreciation of an emerging art // International Journal of Qualitative Methods, 3 (4), Article 3. 395.

Ellis, C. (2016). Revision - Autoethnographic Reflections on Life and Work, 1st Ed.; Routledge, New York, p.

Ellis, C., \& Bochner, A. (2006). Communication As Autoethnography. In Communication as...: Perspectives on Theory, G. Shepherd, J. St. John, \& T. Striphas, Eds., Thousand Oaks, CA: Sage.

Ellis, C., Adams, T. E., \& Bochner, A. (2010). Autoethnography: An Overview // Historical Social Research, Vol. 12: 273-290.European Commission. (2012). Communication from the Commission to the European Parliament, the Council, The European Economic and Social Committee and the Committee of the Regions. Innovating for Sustainable Growth: A Bioeconomy for Europe (COM/2012/60 final), European Commission: Brussels, Belgium, 2012. https://ec.europa.eu/research/bioeconmy/pf/official-strategy_en.pdf.

European Commission. (2018). Communication from the Commission to the European Parliament, the Council, the European Economic and Social Committee and the Committee of the Regions. A sustainable Bioeconomy for Europe: Strengthening the connection between economy, society and the environment (COM/2018/673 final). - https://eurlex.europa.eu/legal-content/EN/TXT/?uri=CELEX:52018DC0673.

Guellec, D., Cervantes, M. and Grubler, A. (2020). Innovation and New Technology for Enabling Economic and Social Progress. In Systemic Thinking for Policy Making: The Potential of Systems Analysis for Addressing Global Policy Challenges in the 21st Century, Hynes, W., Lees, M., \& Müller, J.M., eds; Paris, France: New Approaches to Economic Challenges, OECD Publishing.

Holt, N. L. (2003). Representation, Legitimation, and Autoethnography: An Autoethnographic Writing Story // International Journal of Qualitative Methods. Vol. 2, Iss. 1: 18-28.

Hynes, W., Lees, M., \& Müller, J. M. (eds.) (2020). Systemic Thinking for Policy Making: The Potential of Systems Analysis for Addressing Global Policy Challenges in the 21st Century // New Approaches to Economic Challenges, OECD Publishing, Paris.

Issa, I., Delbrïck, S., \& Hamm, U. (2019). Bioeconomy from experts' perspectives - Results of a global expert survey // PLOS ONE 14 (5).

Krieger, S. (1996). Beyond Subjectivity. In Journeys through ethnography: realistic accounts of fieldwork, Lareau, A. \& Schultz, J. eds., Colorado, Westview Press: 179-194.

Kriščiūnaitè, V., \& Pranskūnienè, R. (2020). Between dark and sustainable tourism // Regional Formation and Development Studies, Klaipeda, Vol. 2. No. 31: 208-219.

Kuckertz, A. (2020). Bioeconomy Transformation Strategies Worldwide Require Stronger Focus on Entrepreneurship // Sustainability. Vol. 12. No. 7: 2911.

Küpers, M. W. (2020). From the Anthropocene to an 'Ecocene' -Eco-Phenomenological Perspectives on Embodied, Anthrodecentric Transformations towards Enlivening Practices of Organising Sustainably // Sustainability, Vol. 12, 3633.

Leach, M., Scoones, I\& Stirling, A. (2010). Governing epidemics in an age of complexity: Narratives, politics and pathways to sustainability. Global Environmental Change, forthcoming. - doi:10.1016/j.gloenvcha.2009.11.008.

Lobe, B., Morgan, D. \& Hoffman, K. A. (2020). Qualitative Data Collection in an Era of Social Distancing // International Journal of Qualitative Methods. 19.

Marcysiak, T. \& Prus, P. (2017). Auto-ethnographic techniques as an efficient tool for reconstruction of rural social capital and local identity // Rural development 2017: bioeconomy challenges: proceedings of the 8th international scientific conference, 1174-1178.

Olmos-López, P., Tusting, K. (2020). Autoethnography and the study of academic literacies: exploring space, team research and mentoring // Trabalhos em Linguística Aplicada, 59 (1): 264-295.

Pranskuniene, R., \& Perkumiene, D. (2021). Public Perceptions on City Landscaping during the Outbreak of Coronavirus Disease: The Case of Vilnius Pop-Up Beach, Lithuania // Land, Vol. 10. No. 1, 32. 
Sari, Y., Pranskūnienè, R., Ece, C., \& Ezenel, E. (2020). Experiences at ESOGÜ tourism camp: a grounded theory approach. In Travel and tourism: sustainability, economics, and management issues, Coşkun İ., Othman N., Aslam, M., Lew, A eds., Singapore: Springer: 331-342.

Scarlat, N., Dallemand, J. F., Monforti-Ferrario F., Nita V. (2015). The role of biomass and bioenergy in a future bioeconomy: Policies and facts // Environmental Development, Vol. 1. No.15: 3-34.

Scarles, C., Sanderson, E. (2016). Becoming researched: the opportunities of autoethnography in tourism research // Travel and Tourism Research Association: Advancing Tourism Research Globally, 68.

Schlaile, M.P.; Klein, K.; Bock, W. (2016). From bounded morality to consumer social responsibility: A transdisciplinaryapproach to socially responsible consumption and its obstacles. J. Bus // Ethics, 1-28.

Schrevel, S., Slager, M., \& de Vlugt, E. (2020). "I Stood By and Watched”: An Autoethnography of Stakeholder Participation in a Living Lab // Technology Innovation Management Review, Vol. 10. No. 11: 19-30.

Stephens Griffin, N. \& Griffin, N. (2019). A Millennial Methodology? Autoethnographic Research in Do-ItYourself (DIY) Punk and Activist Communities [47 paragraphs] // Forum Qualitative Sozialforschung / Forum: Qualitative Social Research, Vol. 20 (3), Art. 3.

Stern, T., Ploll, U., Spies, R., Schwarzbauer, P., Hesser, F., \& Ranacher, L. (2018). Understanding Perceptions of the Bioeconomy in Austria-An Explorative Case Study // Sustainability, Vol. 10: 4142.

Urmetzera, S. Laskb, J. Vargas-Carpinterob, R., \& Pykaa, A. (2020). Learning to change: Transformative knowledge for building a sustainable bioeconomy // Ecological Economics, 167.

Viaggi, D. (2018). The Bioeconomy: Delivering Sustainable Green Growth. CABI, Wallingford, UK, p. 225.

Wall, S. (2006). 'An autoethnography on learning about autoethnography' // International Journal of Qualitative Methods, Vol. 5. No. 2: 146-160. 